\title{
Interferon-Gamma Release Assay
}

National Cancer Institute

\section{Source}

National Cancer Institute. Interferon-Gamma Release Assay. NCI Thesaurus. Code

C128363.

A blood test that exposes a person's lymphocytes ex vivo to two or three

Mycobacterium tuberculosis-specific antigens; a positive result suggests that the person has tuberculosis infection. 